UDC 811.11

\title{
MULTIMODAL REPRESENTATION OF THE ENGLISH CONCEPTUAL DUPLEX HOUSE/HOME
}

\section{I.V. Davydenko, PhD, I.S. Shevchenko, Dr. Hab. (Kharkiv)}

Davydenko I.V. Shevchenko I.S. Multimodal representation of the English conceptual duplex HOUSE/HOME. This paper focuses on the English conceptual duplex HOUSE/HOME, its conceptual properties and means of linguistic representation; and examines the contribution of the data of its multimodal discourse actualization to the cognitive linguistics framework. In cognitive semantics, HOUSE/HOME proves to be a conceptual duplex constituted by various meanings of the polysemantic nouns house and home, and elaborated by the meanings of their synonyms. Within a conceptual network, their common meanings are arranged according to the domains where they are profiled: HUMAN LOCATION / DWELLING, FAMILY. The study of their salience in speech (in literary texts) considers their contextual elaborations, and establishes groups of lexical-semantic variants which are finally blended together within a conceptual model of HOUSE/HOME. This model is a unity of an integral and two differential parts. The integral part is constituted by the meanings: "building where a person lives (with his family)", "dwelling place", family life", "family" shared by the lexemes house (n) and home (n). The differential parts of the model are formed by the meanings which are specific for each polysemantic lexeme. To analyse the HOUSE/HOME actualization in discourse the study adopts a broad perspective on multimodality. It relies on the interaction of verbal and graphic codes and reveals that these semiotic systems are non-isomorphic in representing various meanings of the concept duplex.

Key words: concept duplex HOUSE/HOME, conceptual domain, conceptual network, lexical meaning, multimodality, polysemy, semiotics, synonym.

Давиденко I.B., Шевченко I.C. Мультимодальна репрезентація англомовного дублетного концепту HOUSE/HOME. Ця стаття зосереджується на англійському дублетному концепті HOUSE/HOME, його концептуальних ознаках та засобах мовної репрезентації, а також вивчає дані про його актуалізацію у мультимодальному дискурсі, що поглиблює його розуміння у когнітивній лінгвістиці. 3 точки зору когнітивної семантики HOUSE/HOME виявляється дублетним концептом, що складається з різних значень полісемічних іменників house і home і уточнюється значеннями їхніх синонімів. У межах концептуальної мережі концепту їхні спільні значення впорядковані за доменами, у яких вони профільовані: мІСцЕ ПРОЖИВАННЯ / БУТТЯ ЛЮДИНИ, СІМ'Я. Вивчення їх виділеності в мовленні (у літературних текстах) дозволяє прослідкувати їхні контекстні уточнення, згрупувати їхні лексико-семантичні варіанти, які об'єднуються в рамках концептуальної моделі HOUSE/HOME. Ця модель являє собою єдність інтегральної та двох диференційних частин. Інтегральна частина утворена значеннями: "будинок, де людина живе (разом з сім'єю)", "місце проживання", "сімейне життя", "сім'я", спільними для лексем house (n) i home (n). Диференційні частини моделі сформовані значеннями, специфічними для кожної з багатозначних лексем. Для аналізу представлення HOUSE/HOME в дискурсі у дослідженні використовується широке розуміння мультимодальності. Воно спирається на взаємодію вербальних та графічних кодів i виявляє неізоморфність цих семіотичних систем у поданні ними окремих значень дублетного концепту.

Ключові слова: дублетний концепт HOUSE/HOME, концептуальна мережа, концептуальний домен, лексичне значення, мультимодальність, полісемія, семіотика, синонім.

Давиденко И.В., Шевченко И.С. Мультимодальная репрезентация англоязычного дублетного концепта HOUSE/HOME. Эта статья посвящена анализу английского дублетного концепта HOUSE/HOME, его концептуальных признаков и способов языковой репрезентации, а также изучению данных о его актуализации в мультимодальном дискурсе, что углубляет его понимание в когнитивной лингвистике. С точки зрения когнитивной семантики HOUSE/HOME оказывается дублетным концептом, состоящим из различных значений многозначных существительных house и home, уточненных значениями их синонимов. В рамках концептуальной сети концепта их общие значения упорядочены в соответствии с

(C) Davydenko I.V., Shevchenko I.S., 2018 
доменами, в пределах которых они профилируются: МЕСТО ЖИТЕЛЬСТВА / ПРЕБЫВАНИЯ ЧЕЛОВЕКА, СЕМЬЯ. Изучение их выделенности в речи (в литературных текстах) позволяет проследить их контекстные уточнения, сгруппировать их лексико-семантические варианты, которые объединяются в рамках концептуальной модели HOUSE/HOME. Эта модель представляет собой единство интегральной и двух дифференциальных частей. Интегральная часть образована значениями: "дом, где человек живет (вместе с семьей)", "место жительства", "семейная жизнь", "семья", общими для лексем house (n) и home (n). Дифференциальные части модели сформированы значениями, специфичными для каждой из многозначных лексем. В нашем исследовании анализ представления HOUSE/HOME в дискурсе базируется на широком понимании мультимодальности. Оно опирается на взаимодействие вербальных и графических кодов и обнаруживает неизоморфность этих семиотических систем в представлении отдельных значений дублетного концепта.

Ключевые слова: дублетный концепт HOUSE/HOME, концептуальная сеть, концептуальный домен, лексическое значение, мультимодальность, полисемия, синоним, семиотика.

\section{Introduction}

This paper explores the English lexicalized concept HOUSE/HOME in light of current advances in cognitive linguistics, and examines their presentation in multimodal literary texts so that the data of the graphic code contribute to the cognitive linguistic and cognitive semiotic frameworks. The research on HOUSE/HOME that has been carried out so far mainly treats the topic semantically. The HOUSE/HOME concept has drawn much attention of various disciplines: semiotics $[11 ; 16]$, sociology [9], psychology [15], mythology, history, etc. The $\mathrm{relevance}$ of our study is determined, on the one hand, by the necessity to work out a cognitive explanation of polysemantic properties of lexemes house, home and their synonyms, and on the other, by the need to account for the multimodal presentation of HOUSE/HOME as one of the key concepts of the culture of the English-speaking society. In this study we aim to answer the questions:

(1) what are the properties and nature of the HOUSE/HOME concept; (2) which of these properties are presented in a graphic form in multimodal printed fiction, and (3) what are the relations between verbal and graphic code systems: whether they are isomorphic in representing the meanings of the concept?

The purpose of this study is to model the HOUSE/HOME concept, which is represented by different meanings of the English polysemantic nouns house and home and their synonyms, and, more specifically, to trace how these meanings manifest themselves in different code systems in multimodal texts. In this paper, we argue that the theoretical approach of cognitive linguistics and cognitive semiotics is particularly well suited to achieve this task.

The object of this study is the HOUSE/HOME concept, verbalized by polysemantic lexemes house and home and their synonyms, and presented by graphic means in the English fiction. The mate rial of the study is vocabulary definitions of the polysemantic nouns houses and home and about 500 of their synonyms, the occurrence of these lexical units in modern English texts from the BNC database (fiction) as well as corresponding pictures from modern books of fiction.

\section{Theoretical Underpinnings and Research Methods}

This study is carried out in the context of cognitive linguistics and cognitive semiotics, and focuses on the representation of the HOUSE/HOME concept in the English lexical units and drawings in printed books of fiction. The most relevant approach for the analysis of the former is cognitive semasiology which is concerned with the cognitive mechanisms behind the development of the multiple meanings (or polysemy).

The consideration of the actual research material is carried out with the help of a complex methodology, which includes the method of analysis of vocabulary definitions (to distinguish the lexicalsemantic variants of nouns house and home), the method of lexical component analysis (to find out the meanings of lexical-semantic variants and the synonymic rows formed on their basis), as well as methods of conceptual networks construction (to reproduce conceptual nets of polysemantic nouns house and home). According to S. Zhabotynska [6], 
conceptual models of polysemy are networks reproduced by various combinations of quantitatively limited generalized propositions (schemes), which are part of basic frames [6, c.357368].

The studies in multimodality carried out within the field of semantics have postulated that meanings are construed along various interaction patterns of linguistics and semiotics. The pivotal point in this development was the publication of the book by Gunter Kress and Theo van Leeuwen who argue that "semiotic modes, similarly, are shaped by both the intrinsic characteristics and potentialities of the medium and by the requirements, histories and values of societies and their cultures" [20, c.35]. Today researchers agree that multimodality has quickly become "the normal state of human communication" [19]. As John A. Bateman puts it in his book Multimodality and Genre, "Nowadays... text is just one strand in a complex presentational form that seamlessly incorporates visual aspect 'around', and sometimes even instead of, the text itself" [18]. These ideas serve the underpinnings of our analysis of the representation f meanings of the HOUSE/HOME concept in the form of drawings illustrating modern English fiction.

We carry out the analysis of the HOUSE/HOME concept in four stages.

At the first stage, we determine the list of lexicalsemantic variants for house and home according to dictionaries.

At the second stage, the object of analysis becomes only the conceptual domain within the conceptual networks of lexical-semantic variants directly related to the HOUSE/HOME concept.

At the third stage of the analysis, we build an integrative conceptual model that combines the lexical semantic variants of home and house, which are profiled within the domain HUMAN LOCATION. This model structures the HOUSE/HOME concept as a conceptual duplex.

At the final stage, we analyze how various meanings of the HOUSE/HOME concept are conceptualized through visual imagery in multimodal texts of fiction.

\section{Results and Discussion}

The notion HOUSE/HOME is a cultural universality, one of the main material conditions of human existence. The modern concept HOUSE/HOME goes back to biblical and mythological notions. The Bible interprets the concept as "housing", "protection", "storage", "family life", "household", "family", "genus", "household, united by faith" [13].

The origins of this concept lie in the mythology being "the starting point of the evolution of the concept" [14]. HOUSE/HOME is conceived as the center of the world and personified as ancestors' spirits. HOUSE/HOME is a cosmic symbol, a reduced model of the universe. The symbols of HOUSE/HOME are the fire / fireplace as the organizing center of the home, a sign of the spiritual and material unity of relatives living together, of the beginning of life.

In linguistics, depending on the direction of research, the analysis of the HOUSE/HOME concept focuses on various aspects.

In linguistic-cultural studies, HOME is interpreted as basic knowledge, a network of coordinates that simulates the relationship between man and the world, that is, one of the concepts that constitutes a popular world view [7]. As a linguocultural concept, HOME (represented by the phraseological means of English) is considered to be a macro-ethnic concept consisting of the concepts HOUSE and HOME [17]. Historical and cognitive research of the concept reveals diachronic changes in its meanings and, accordingly, in the semantics of its names - the lexemes house and home [5].

In linguistic poetics, the concept HOME/HOUSE is interpreted as depending on the author's idiostyle [12] and his/her artistic world view [1]. The attention of researchers is paid to how the HOUSE/HOME concept is denoted by its names house and home. This question is central in our work, too.

The study of the concept in the direction "from culture to individual consciousness" [8] includes the disclosure of its pre-conceptual basis - the direct psychic data, rooted in cult thinking and not yet conceived [2]. This psychic value is an archetype unconscious knowledge, presented in the mind by certain images, symbols and myths. The notion of HOME, as phraseology proves, dates back to such archetypes as SELF (the orientation of the living space on the center - the hearth / fireplace, the home represents the area of the soul, where the center is 
the location of self: i.e. the home is where the heart $i s$ ), SHADOW (the labyrinth, cellar symbolizing the other world: to go one's last home), WISE OLD MAN (the personification of the well-ordered internal space in comparison with the outer chaos, the traditions of the generation (i.e. be as safe as houses, the Englishman's house is his castle), WISE OLD WOMAN (home is women's kingdom), MASK (the suitability of housing for the social role of its owner: a bachelor home).

The means of lexical representation of HOUSE/HOME in English include several basic synonyms: nouns house, home, building, dwelling, abode, household, where the first two possess a prevailing semantic potential. The number of their meanings varies significantly: house and home have 21 and 22 lexical semantic variants respectively, while the others have no more than $2-4$ each. The contents of house and home completely cover the contents of their synonyms.

To model the conceptual polysemy we first single out the semantic properties of house and home. The etymological layer of the concept (the term by Yu.S. Stepanov [14]) is formed by the meanings "hide" and "settle down" (for house from PrGr *Khusan "hide" and home - PrInd *Tkei -"settle"); this determines their internal forms - "protection" (house) and "dwelling" (home).

In historic perspective, their polysemantic nature is a result of lexical processes based on the metaphor, metonymy, expansion and narrowing of concepts. In lexicographic data, house is fixed by dictionaries in the $10^{\text {th }}-21^{\text {st }}$ centuries, home - in the $19^{\text {th }}-21^{\text {st }}$ centuries (OED). Based on generalized propositions (schemes), the conceptual models of their polysemy are networks, part of the basic operational frames [6]. The propositions are thematically grouped within them and serve as a tool to build frame networks of specific subject domains. The most prominent domain is HUMAN LOCATION, it represents the networks of polysemy for both home and house. Together, they construct an integrated "conceptual duplex" HOUSE/HOME [3; 4].

An integrated conceptual model of the duplex HOUSE/HOME profiled within the domain HUMAN LOCATION is connected by partitative, locative, classification schemes, etc. [3; 4]. In our data, prevailing meanings of home are "family life", "dwelling", "building where a person lives (with his family)", "family"; while house has dominant meanings "building where a person lives (with his family)", "institution / body" [4, c.87-94].

The meanings "building where a person lives (with his family)", "dwelling place", "family life"," family" are profiled within the domain HUMAN LOCATION, They are common both for house and home, and form the integral area of their conceptual polysemy networks, and, correspondingly, the integral area of the conceptual duplex HOUSE/HOME.

Two differential areas of the conceptual duplex HOUSE/HOME are formed by other meanings respectively [4, c.87-94]:

- HOME area - "people - residents of the dwelling", "the place where the house is located", "the place where the parent's home is", "the organization that cares about people who need help: types of organizations ";

- HOUSE area - "dynasty / old tribe", "university dormitory", "group of students living in a university dormitory", "commercial organization: types of organizations", "staff / management of the organization", "house of the legislative body", "quorum of the legislative body", "entertaining institution", "audience in the theater".

In illustrated books of fiction, the meaning is jointly created in graphic and linguistic signs though they highlight different properties of the HOUSE/HOME concept duplex.

In children literature, the meanings of HOUSE prevail in graphic representation: for example, in "Winnie-the-Pooh" by Alan Milne with the original colour illustrations by E.H. Shepard one finds the map with the drawings of Pooh Bear's house, Rabbit's house, Piglet's house, Kangas house, Owle's house [21, c. 8].

In linguistic representation, metonymy often represent the meaning of "building where a person lives" is (by synecdoche - the door stands for the house):

So Winnie-the-Pooh went round to his friend Christopher Robin, who lived behind a green door in another part of the Forest [21, c. 10],

as well as the meaning of "dwelling place" (the route stands for the house):

So when Christopher Robin goes to the Zoo, he goes to where the Polar Bears are, and he whispers 
something to the third keeper from the left, and doors are unlocked, and we wander through dark passages and up steep stairs, until at last we come to the special cage, and the cage is opened, and out trots something brown and furry, and with a happy cry of 'Oh, Bear!' Christopher Robin rushes into its arms. $[21$, c. 6].
The meanings "family life"," family", associated with the concept area of HOME, are mostly represented linguistically, i.e. East or West - home is best, A home can be made a heaven or a hell. They are not common in graphic representation, and are illustrated schematically or symbolically (through the symbols of the heart (LOVE), flowers (COSINESS) etc.:

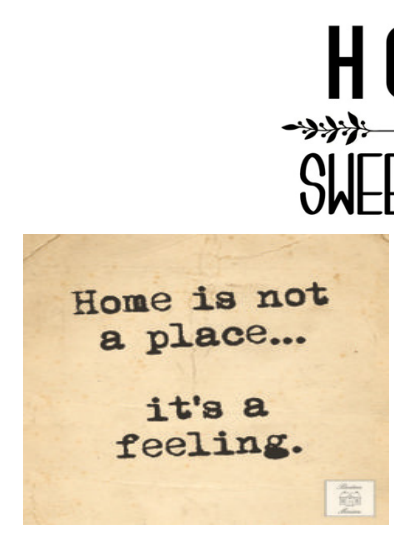

To s u m it u p, both verbal and visual construing of the meaning of HOME / HOUSE in multimodal texts requires a corporeal involvement of the reader. In our examples, graphic and linguistic signs make salient different components of the common meanings of the concept duplex. This proves the fact that verbal and visual (graphic) codes are not isomorphic in representing the HOME / HOUSE concept.

\section{Conclusion}

The present study has focused on the exploration of a lexical conceptual duplex HOUSE/HOME verbalized by the polysemantic nouns house, home, and their synonyms. Our analysis has revealed that the HOUSE/HOME concept can be modeled as a unity of an integral and two differential parts. The former comprises the meanings: "building where a person lives (with his family)", "dwelling place", "family life", and "family". The differential areas of the conceptual duplex correspond to the concept area HOME ("people - residents of the dwelling", "the place where the house is located", "the place where the parent's home is", "the organization that cares about people who need help: types of organizations " - for the concept); and the concept area HOUSE ("dynasty / old tribe", "university dormitory", "group of students living in a university dormitory", "commercial organization: types of organizations", "staff/management of the organization", "house of the legislative body", "quorum of the legislative body", "entertaining institution", "audience in the theater").

Our data also confirm the importance of paying close attention to various modes of representing the concept meanings in multimodal texts. In multimodal texts of English fiction, both graphic and linguistic codes represent the HOUSE/HOME concept but are not isomorphic. Linguistic and visual semiotic systems prove to be used preferably to represent different components of the meaning of this conceptual duplex.

The perspective vector for a further research can be a diachronic cognitive analysis of the polysemantic house and home, as well as other conceptual duplexes which will reveal their evolution in linguistic and in other semiotic systems.

\section{ЛІТЕРАТУРА}

1. Богатова С.М. Концепт ДОМ как средство исследования художественной картины мира Вирджинии Вулф : автореф. дис. на соискание учен. степени канд. филол. наук : спец. 10.02.04. «Германські мови». Омск, 2006. 20 с. 2. Бєлєхова Л.І. Словесний поетичний образ в історико-типологічній перспективі: лінгвокогнітивний аспект : монографія. Херсон : 
Айлант, $\quad 2002 . \quad 368$ c. $\quad$ 3. Давыденко И.В. Концептуальная сеть полисемии полисеманта house (n.) - имени концепта ДОМ / HOUSE // Когнітивнопрагматичні дослідження професійних дискурсів : матеріали Третьої міжнародної наукової конференції. Харків. нац. ун-т імені В.Н. Каразіна (19 бер. 2011). С. 25-28. 4. Давыденко И.В. Концептуальная сеть полисемии полисеманта home (n.) - имени концепта ДОМ / НОМЕ» // Вісник Харків. нац. ун-ту імені В.Н. Каразіна. 2011. № 953. С. 87-94. 5. Єсипенко Н.Н. Концепт home в англійській літературі XVIII століття// Наукові записки Чернівец. держ. ун-ту. Серія: філологічні науки. Вип. 89 (1). С. 296-300. 6. Жаботинская С.А. Принципы лингвокогнитивного анализа и феномен полисемии // Проблеми загального, германського та слов'янського мовознавства. До 70-річчя професора В.В Левицького : збірник наук. праць. Чернівці, 2008. С. 357-368. 7. Житникова М.Л. Дом как базовое понятие народного мировидения: (лингвокультурологический аспект) : дис. ... канд. филол. наук : 10.02.01.Томск, 2006. 191 с. 8. Карасик В.И. Языковая кристаллизация смысла: монография. Волгоград: Парадигма, 2010. 422 с. 9. Козырьков В.П. Теоретические проблемы становления социологии дома // Личность. Культура. Общество. Вып. ХІ (2009), № 1. С. 301-309. 10. Миличич Б. Изучение родства, символическое мышление и преистория в антропологии XXI века //Международный журнал по антропологии и археологии: Stratum plus, (2010), № 2. С. 15-21. 11. Невская Л.Г. Семантика дома и смежных представлений в погребальном фольклоре // Балто-славянские исследования. М., 1982. С. 106-121. 12. Подкопаева А.А. Вербализация художественного концепта "Home/House" в произведениях английских писателей XIX-XX вв. : дис. доктора филол. наук : 10.02.19. Ставрополь, 2010. 234 с. 13. Ринекер Ф., Майер Г. Библейская энциклопедия Брокгауза ; пер. с нем. Оригинальное издание: Lexikon zur Bibel.1994 Brokhaus Verlag Wuppertal [Электронный pecypc]. 1994. Режим доступа : http://dic.academic.ru/ 14. Степанов Ю.С. Константы: Словарь русской культуры. Опыт исследования. М.: Школа "Языки русской культуры", 1997. 824 с. 15. Фрейд 3. Введение в психоанализ : Лекции. М. : Наука, 1990. 280 с. 16. Цивьян Т.В. Дом в фольклорной модели мира (на материале балканских загадок) // Труды по знаковым системам. Тарту, 1978. Вып. 10. С. 65-85. 17. Чернобай С.Е. Концепт «дом» в английской фразеологической картине мира // Ученые записки
Таврич. нац. ун-та имени В.И. Вернадского. Серия «Филология. Социальные коммуникации». Том 23 (62). № 3. 2010. C. 136-140. 18. Bateman J.A. Multimodality and Genre: A Foundation for the Systematic Analysis of Multimodal Documents. New York: Palgrave Macmillan, 2008. 312 p. 19. Kress G. Multimodality: A Social Semiotic Approach to Contemporary Communication. New York: Routledge, 2010. 212 p. 20. Kress G., van Leeuwen Th. Reading Images : the grammar visual design. London: Routledge, 1996.

\section{ІЛЮСТРАТИВНИЙ МАТЕРІАЛ}

Milne A.A. Winnie-the-Pooh with the original colour illustrations by E.H. Shepard. London: E. H. Shepard and Egmont Books Limited, 1974. 151 p. Available at www.egmont.co.uk

\section{REFERENCES}

Bateman, J.A. (2008). Multimodality and Genre: A Foundation for the Systematic Analysis of Multimodal Documents. New York: Palgrave Macmillan. 312 p.

Bogatova, S.M. (2004). Kontsept DOM kak sredstvo issledovaniya khudozhestvennoy kartiny mira Virdzhinii Vulf. Avtoref. diss. kand. filol. Nauk [Concept HOUSE as a means of studying the artistic picture of the world by Virginia Woolf. Cand. philol. sci. diss. synopsis]. Omsk. 20 p. (in Russian).

Byelyekhova, L.I. (2002) Slovesnyy poetychnyy obraz $v$ istoryko-typolohichniy perspektyvi: linhvokohnityvnyy aspekt [A verbal poetic image in the historical-typological perspective: linguocognitive aspect]. Kherson: Aylant Publ. (in Ukranian).

Chernobay, S.Ye. (2010). Kontsept «dom» v angliyskoy frazeologicheskoy kartine mira [The concept of "house" in the English phraseological worldview]. Uchenyye zapiski Tavrich. nats. un-ta imeni V.I. Vernadskogo. Seriya «Filologiya. Sotsial'nyye kommunikatsii».- Academic notes of Tavrich. Nat. University named after V.I. Vernadsky. Series "Philology. Social communications. Volume 23 (62). № 3, 136-140 (in Russian).

Davydenko, I.V. (2011). Kontseptual'naya set' polisemii polisemanta house (n.) - imeni kontsepta DOM / HOUSE [Conceptual network of polysemy of house (n.) - the name of the concept HOUSE]. Kohnityvno-prahmatychni doslidzhennya profesiynykh dyskursiv : materialy Tret'oyi mizhnarodnoyi naukovoyi konferentsiyi. Kharkiv. nats. un-t imeni V.N. Karazina. - Cognitive-pragmatic studies of professional discourses: materials of the Third International Scientific Conference. Kharkiv National 
University named after V.N. Karazin (March, 19, 2011), 25-28 (in Russian).

Davydenko, I.V. (2011). Kontseptual'naya set' polisemii polisemanta home (n.) - imeni kontsepta DOM / HOME [Conceptual network of polysemy of home (n.) - the name of the concept HOME]. Visnyk Kharkiv. nats. un-tu imeni V.N. Karazina.- V.N. Karazin Kharkiv. National Univ. Messenger, 953, 8794 (in Russian).

Freud, Z. (1990) Vvedeniye v psikhoanaliz : Lektsii [Introduction to psychoanalysis: Lectures] Moscow : Nauka Publ. (in Russian)

Karasik, V.I. (2010) Yazykovaya kristallizatsiya smysla [Linguistic crystallization of meaning]. Volgograd: Paradigma Publ. (in Russian).

Kozyr'kov, V.P. (2009). Teoreticheskiye problemy stanovleniya sotsiologii doma [Theoretical problems of the formation of sociology of home]. Lichnost'. Kul'tura. Obshchestvo. - Personality. Culture Society. Issue XI, No. 1, 301-309 (in Russian).

Milichich, B. (2010). Izucheniye rodstva, simvolicheskoye myshleniye $i$ preistoriya $\mathrm{V}$ antropologii XXI veka [The study of kinship, symbolic thinking and prehistory in anthropology of the XXI century]. Mezhdunarodnyy zhurnal po antropologii $i$ arkheologii. - International Journal of Anthropology and Archeology: Stratum plus, № 2, 15-21 (in Russian).

Nevskaya, L.G. (1982). Semantika doma i smezhnykh predstavleniy $\mathrm{v}$ pogrebal'nom fol'klore [The semantics of the house and related representations in the burial folklore]. Balto-slavyanskiye issledovaniya. - Baltic-Slavic studies, 106-121 (in Russian).

Podkopayeva, A.A. (2010). Verbalizatsiya khudozhestvennogo kontsepta "Home/House" $v$ proizvedeniyakh angliyskikh pisateley $X I X-X X v v$. Diss. doc. filol. nauk [Verbalization of the artistic concept "Home / House" in the works of English writers of the XIX - XX centuries. Dr. philol. sci. diss]. Stavropol'. 234p. (in Russian).

Ryneker, F., Meyer G. (n.d.). Biblical Encyclopedia of Brockhaus. Available at: http://dic.academic.ru/

Stepanov, YU.S. (1997) Konstanty: Slovar' russkoy kul'tury. Opyt issledovaniya [Constants: Dictionary of Russian culture. Research experience]. Moscow: Shkola "Yazyki russkoy kul'tury" Publ.

Tsiv'yan, T.V. (1978). Dom v fol'klornoy modeli mira (na materiale balkanskikh zagadok) [House in the folklore model of the world (on the material of the Balkan riddles)]. Trudy po znakovym sistemam. Works on sign systems. Vol. 10, 65-85 (in Russian).

Yesypenko, N.N. (2010). Kontsept home v anhliys'kiy literaturi XVIII stolittya [Concept home in the English literature of the XVIII century]. Naukovi zapysky Chernivets. derzh. un-tu. Seriya: filolohichni nauky. - Scientific notes of Chernivti State University: philological sciences. Issue 89 (1), 296-300 (in Ukranian).

Zhabotinskaya, S.A. (2008). Printsipy lingvokognitivnogo analiza $i$ fenomen polisemii [Principles of linguistic and cognitive analysis and the phenomenon of polysemy]. In: G. Altmant (ed.). Problemy zahal'noho, hermans'koho ta slov"yans'koho movoznavstva. Do 70-richchya profesora V.V. Levyts'koho : zbirnyk nauk. prats'. [Problems of Germanic and Slavic linguistics. To the 70th anniversary of Professor V.V. Levitsky: Collection of Scient. Works].pp. 357-368 (in Russian)

Zhitnikova, M.L. (2006). Dom kak bazovoye ponyatiye narodnogo mirovideniya: (lingvokul'turologicheskiy aspekt). Diss. kand. filol. nauk [House as a basic concept of popular worldview: (linguocultural aspect). Cand. philol. sci. diss]. Tomsk. 191 p. (in Russian)

Давиденко Інна Володимирівна - кандидат філологічних наук, доцент кафедри ділової іноземної мови та перекладу Харківського національного університету імені В.Н. Каразіна; e-mail: i.v.davydenko@karazin.ua; SCHOLAR GOOGLE: https://scholar.google.com.ua /citations?view_op=list_works\&hl=uk\&user=zHXXc6QAAAAJ.

Шевченко Ірина Семенівна - доктор філологічних наук, професор, завідувач кафедри ділової іноземної мови та перекладу Харківського національного університету імені В.Н. Каразіна; е-mail: irina.shevchenko7@gmail.com; ORCID: https://orcid.org/0000-0003-2552-5623; SCHOLAR GOOGLE: https://scholar.google.com.ua/citations?user=uHkA_kgAAAAJ\&hl=ru. 